\title{
Quality Characteristics and Free Amino Acid Content of Seasoning Pork Meat Aged by Red Wine
}

Kyung-Suk Park', Kyung-Soo Lee ${ }^{2}$, Hyun-Sook Park', Young-Jun Choi', Se-Ju Kang ${ }^{3}$, Jong-Beom Yang ${ }^{4}$, Jae-Seok Hyon ${ }^{5}$, In-Chul Jung ${ }^{1}$ and Yoon-Hee Moon ${ }^{6}$

\author{
${ }^{1}$ Division of Hotel Culinary Arts, Daegu Technical University, Daegu 704-721, Korea \\ ${ }^{2}$ Division of Food, Beverage and Culinary Arts, Yeungnam College of Science and Technology, Daegu 705-703, Korea \\ ${ }^{3}$ Animal Product Grading Service, Gyonggido 435-010, Korea \\ ${ }^{4}$ Department of Food Science and Biotechnology, Dongnam Health College, Gyeonggi 440-714, Korea \\ ${ }^{5}$ Department of Food and Nutrition, Jeju College and Technology, Jeju 690-714, Korea \\ ${ }^{6}$ Department of Food Science and Biotechnology, Kyungsung University, Busan 608-736, Korea
}

Received September 28, 2010 /Accepted January 17, 2010

\begin{abstract}
This study was carried out to investigate the effects of the addition of red wine on the quality characteristics and free amino acid content of seasoned pork meat. Seasoned pork meat was prepared using three variation: pork meat containing $25 \%$ water (T0), pork meat containing a combination of $20 \%$ water and $5 \%$ red wine (T1), pork meat containing a combination of $15 \%$ water and $10 \%$ red wine (T2), and pork meat containing a combination of $10 \%$ water and $15 \%$ red wine (T3). There were no significant differences in moisture, crude protein, crude fat, crude ash, a value, rheological properties, $\mathrm{pH}, \mathrm{VBN}$ content, saturated fatty acid or unsaturated fatty acid among T0, $\mathrm{T} 1, \mathrm{~T} 2$ and T3. The $\mathrm{L}^{*}$ and $\mathrm{b}^{*}$ value of seasoned pork meat was higher in T2 and T3 than in T0 and T1 $(p<0.05)$. The TBARS value was highest in T0 $(p<0.05)$. The free amino acid content was higher in $\mathrm{T} 2$ and $\mathrm{T} 3$ than in $\mathrm{T} 0(p<0.05)$.
\end{abstract}

Key words : Red wine, seasoning pork meat, quality characteristics, free amino acid

\section{서 론}

돈육은 우리나라 사람들이 선호하는 식육으로서 삼겹살, 목살, 갈비 등이 수육이나 구이용으로 많이 이용되고 있다. 그러나 소비자들의 일반적인 식품의 소비 형태는 저지방 식 품을 선호하는 경향이 있어서 식육의 소비 형태와는 대조를 이룬다. 따라서 돈육의 경우 지방함량이 낮아 비선호 부위로 분류되는 뒷다리, 앞다리, 등심 등은 조리용이 아닌 가공용으 로 이용하는 경우가 많다. 그 중에서 돈육 뒷다리 및 등심은 생산수율이 각각 $30.9 \%$ 및 $12.9 \%$ 로 많은 양을 차지하고 있어 [31] 이의 활용방법을 연구한 결과 햄, 패티, 소시지, 육포 등 다양한 가공품의 원료로 이용되고 있으며, 여러 가지 조미원 료를 첨가한 양념육으로도 이용되고 있다. 양념육은 기호성 의 향상을 위하여 조미원료로서 주로 간장을 사용하고 있는 데, 간장의 짠맛, 구수한 맛, 단맛, 신맛 등이 조화를 이루고 있다[16]. 또 양념육의 냄새와 맛을 개선하기 위하여 첨가하 는 양파, 파, 마늘, 생강 등은 다양한 약리작용을 가지고 있어 서[3,22,32] 현대사회가 요구하는 건강식품으로서도 적당하 다. 최근에는 육제품에 생리활성기능이 있는 물질을 첨가하

*Corresponding author Tel : +82-53-560-3854, Fax : +82-53-560-3859

E-mail : inchul3854@hanmail.net
여 인간의 건강에 초점을 맞춘 것들이 많이 연구되고 있다. 그 중에서 적포도주는 quercetin, myricetin, catechin, epicatechin 등이 함유되어 있어서 지방이 많은 육류와 잘 어울 리는 것으로 알려져 있다[2].

적포도주는 "French paradox", 즉 프랑스 사람들이 심장병 발병이 적은 것은 와인을 많이 마시기 때문이라는 것이 보고 되면서[12] 우리나라 소비자들도 육류를 섭취할 때 적포도주 를 음용하는 것이 늘어나는 추세다. 적포도주에는 다양한 페 놀화합물을 함유하고 있어서[10] 항산화, 항균, 항암, 항염증 작용, 동맥경화 억제, 심장병 억제, $\mathrm{LDL}$-콜레스테롤 산화 억 제, HDL-cholesterol 증가 등 $[1,6,7,9,15,27,29,33]$ 약리작용이 있다. 따라서 적포도주를 육제품 제조에 첨가하면 생리활성 기능을 갖춘 육제품의 생산이 가능할 것으로 여겨진다. 육제 품에 적포도주를 첨가한 연구는 많지 않지만 Youn 등[35]은 돈육 patty에 적포도주를 첨가하였을 경우 TBARS 및 세균의 증식이 억제된다고 하였으며, Lee 등[25]은 육포에 적포도주 를 첨가하였을 경우 $\mathrm{VBN}$ 함량과 총균수를 억제한다고 보고하 였다. 그러나 적포도주를 이용한 육제품의 연구는 깊이 있게 이루어진 것이 없는 실정이다. 따라서 본 연구는 양념돈육을 제조할 때 적포도주를 첨가하고 적포도주가 양념돈육의 품질 에 미치는 영향을 구명하고자 하였다. 


\section{재료 및 방법}

\section{공시재료 및 양념돈육 제조}

돈육은 시중의 대형마트에서 동결상태로 유통되는 등심부 위를 구입하여 $4^{\circ} \mathrm{C}$ 에서 24 시간 해동하고 $5 \times 15 \times 0.5 \mathrm{~cm}$ 로 자른 후 과도하게 붙어있는 지방을 제거하였다. 양념돈육 제조를 위한 양념의 배합비율은 Table 1 과 같다. 즉, 간장 $50 \%$, 설탕 $20 \%$, 대파 $2 \%$, 마늘 $1.5 \%$, 생강 $0.5 \%$, 참기름 $1 \%$ 에 대조구(T0) 는 물 $25 \%, \mathrm{~T} 1$ 은 물 $20 \%$ 와 적포도주 $5 \%, \mathrm{~T} 2$ 는 물 $15 \%$ 와 적포 도주 $10 \%$, 그리고 $\mathrm{T} 3$ 는 물 $10 \%$ 와 적포도주 $15 \%$ 를 첨가하였 다. 여기에 사용된 간장은 $\mathrm{S}$ 사 제품의 혼합간장으로 양조간장 $20 \%$, 산분해간장 $80 \%$ 이었고, 설탕은 $\mathrm{P}$ 사, 레드와인은 알코올 함량 $11.5 \%$ 인 미국 캘리포니아에서 제조된 Carlo Rossi California red였다. 그리고 향신료로 사용된 야채는 대구의 재래시장에서 구입하였으며, 양념돈육은 $4^{\circ} \mathrm{C}$ 에서 24 시간 숙 성하였다.

\section{일반성분 분석}

양념돈육의 수분함량은 상압가열건조법[23], 조단백질은 단백질분석기(Tecator Kjeltec Auto 1030 Analyzer, Korea)로 분석하였으며, 조지방은 지방분석기(Soxtec system 1046, Sweden)를 이용하였고, 조회분은 직접회화법[23]으로 분석하 였다.

\section{표면색깔 측정}

양념돈육의 색깔은 색차계(Chromameter CR-200b, Minolta Camera Co., Japan)를 이용하여 명도(lightness, $\mathrm{L}^{*}$ 값), 적색도 (redness, $a^{*}$ 값) 및 황색도(yellowness, $b^{*}$ 값)를 측정하였다. 이 때 색보정을 위하여 사용된 표준백색판의 $\mathrm{L}^{*}, \mathrm{a}^{*}$ 및 $\mathrm{b}^{*}$ 값은 각각 $97.5,-6.1$ 및 7.4 이었다.

\section{기계적 조직감 측정}

조직감은 근섬유와 평행하게 가로, 세로, 높이를 각각 40 ,

Table 1. Formulation of seasoning pork meat (\%)

\begin{tabular}{lcccc}
\hline Ingredient & $\mathrm{T}^{1)}$ & $\mathrm{T}^{2)}$ & $\mathrm{T}^{3)}$ & $\mathrm{T}^{4)}$ \\
\hline Soy sauce & 50 & 50 & 50 & 50 \\
Sugar & 20 & 20 & 20 & 20 \\
Leek & 2 & 2 & 2 & 2 \\
Garlic & 1.5 & 1.5 & 1.5 & 1.5 \\
Ginger & 0.5 & 0.5 & 0.5 & 0.5 \\
Sesame oil & 1 & 1 & 1 & 1 \\
Water & 25 & 20 & 15 & 10 \\
Red wine & 0 & 5 & 10 & 15
\end{tabular}

${ }^{1)}$ Seasoning pork meat containing water $25 \%$.

${ }^{2}$ Seasoning pork meat containing water $20 \%$ and red wine $5 \%$.

${ }^{3}$ Seasoning pork meat containing water $15 \%$ and red wine $10 \%$.

${ }^{4}$ Seasoning pork meat containing water $10 \%$ and red wine $15 \%$.
15 및 $5 \mathrm{~mm}$ 로 자르고 rheometer (CR-200D, SUN Scientific Co., Japan)를 이용하여 측정하였다. 이때 경도(hardness), 탄 성(springiness), 응집성(cohesiveness)은 round adapter 25번 을 이용하여 table speed $120 \mathrm{~mm} / \mathrm{min}$, graph interval 30 $\mathrm{m} / \mathrm{sec}$, load cell (Max) $2 \mathrm{~kg}$ 의 조건으로 측정하였다. 뭉침성 (gumminess)은 peak max $\times$ cohesiveness 값으로, 저작성 (chewiness)은 (peak max $\div$ distance) $\times$ cohesiveness $\times$ springiness 값으로 나타내었다.

\section{$\mathrm{pH}$ 측정}

양념돈육의 $\mathrm{pH}$ 측정은 대기온도에서 $\mathrm{pH} 4.00$ 과 $7.00 \mathrm{buffer}$ 로 보정한 유리전극이 부착된 $\mathrm{pH}$ meter (ATI Orion 370, USA)를 이용하여 측정하였는데, 시료는 분쇄한 후 $10 \mathrm{~g}$ 을 취 하여 증류수 $40 \mathrm{ml}$ 와 함께 균질한 후 측정하였다.

\section{VBN함량 측정}

양념돈육의 VBN함량은 Conway unit를 이용한 미량확산 법[23]에 의하여 측정하였다. 즉 양념돈육 $2 \mathrm{~g}$ 을 증류수 $16 \mathrm{ml}$ 와 20\% perchloric acid (Sigma-Aldrich, USA) $2 \mathrm{ml}$ 를 넣고 균질화한 후 $3,000 \mathrm{rpm}$ 에서 15 분 동안 원심분리하여 상층액을 취하였다. 상층액 $1 \mathrm{ml}$ 와 $50 \% \mathrm{~K}_{2} \mathrm{CO}_{3}$ (Sigma-Aldrich, USA) $1 \mathrm{ml}$ 를 Conway unit 외실에 넣고, 내실에는 $10 \%$ 붕산흡수제 (Junsei, Japan)를 $1 \mathrm{ml}$ 가한 후 $37^{\circ} \mathrm{C}$ 에서 80 분 동안 방치한 다음 $0.01 \mathrm{~N}-\mathrm{NaOH}$ (Junsei, Japan)로 적정하여 구하였다.

\section{TBARS값 측정}

양념돈육의 TBARS값은 시료 $2 \mathrm{~g}$ 을 perchloric acid (Sigma-Aldrich, USA) $18 \mathrm{ml}$ 및 BHT $50 \mu \mathrm{l}$ 와 함께 균질화하고 여과한 여과액 $2 \mathrm{ml}$ 에 2-thiobarbituric acid (Sigma-Aldrich, USA) $2 \mathrm{ml}$ 를 가하고 $531 \mathrm{~nm}$ 에서 흡광도를 측정하여 나타난 값을 시료 $\mathrm{kg}$ 당 반응물 $\mathrm{mg}$ malonaldehyde로 계산하였다[4].

\section{지방산조성 분석}

지질은 Folch 등[8]의 방법으로 추출, 정제하고, $14 \%$ $\mathrm{BF}_{3}$-methanol (Sigma-Aldrich, USA) 용액을 사용하여 methylation시켜 이것을 GC (SRI 8610C, USA)로 분석하였다. 사용 한 column은 Quadrex $(30 \mathrm{~m} \times 0.25 \mathrm{~mm}$ I.D., $0.25 \mu \mathrm{m}$ film thickness)이었으며, $250^{\circ} \mathrm{C}$ 의 조건에서 분석하였다.

\section{유리아미노산 분석}

양념돈육의 유리아미노산은 시료 $0.2 \mathrm{~g}$ 에 $75 \%$ ethanol (Burdick \& Jackson, USA)을 가하여 30분간 진탕시켜 10,000 $\mathrm{rpm}$ 에서 10 분간 원심분리하여 얻어진 상층액을 취하고, 남은 잔사에 다시 $75 \%$ ethanol을 가하여 얻어진 상층액과 함께 감 압 농축하여 ethanol을 제거하였다. 이 여액에 $25 \%$ trichloroacetic acid (Junsei, Japan)를 가하여 단백질을 제거하고 ethyl 
ether (Burdick \& Jackson, USA)로 여액 중의 trichloroacetic acid를 제거한 다음 감압 농축하여 잔류한 ethyl ether를 제거 하였다. 이 여액을 Amberlite IR120 $\left(\mathrm{H}^{+}\right)$수지가 충전된 칼럼 에 통과시켜 아미노산을 흡착시킨 다음 $0.2 \mathrm{~N}$ lithium citrate buffer (pH 2.2)로 용해시켜 여과하고, 아미노산분석기 (Pharmacia LKB 4150 Alpha plus, Swden)로 분석하였다. 사 용된 column은 cation exchange column 4151 series II $(200 \times 4.6 \mathrm{~mm})$ 이었으며, lithium citrate hydrate buffer A (Sigma-Aldrich, USA) $\mathrm{pH} 2.85$, lithium citrate hydrate buffer B (Sigma-Aldrich, USA) pH 4.2, lithium chloride buffer (Sigma-Aldrich, USA) pH 3.3을 이용하여 $15 \mathrm{ml} / \mathrm{min}$ 의 유속 으로 용출시켰다[24].

\section{통계처리}

모든 실험결과들은 3회 반복 측정한 평균값을 이용하여 평균 \pm 표준편차로 나타내었으며, 통계처리는 SPSS 14.0 (statistical package for social sciences, SPSS Inc., Chicago II., USA)을 이용하였다. 시료들 사이의 유의성은 $p<0.05$ 수준에서 one-way ANOVA를 실시한 후 유의한 차이가 있는 경우 $p<0.05$ 수준에서 Duncan's multiple range test로 검정하였다.

\section{결과 및 고찰}

\section{양념돈육의 일반성분}

양념돈육의 일반성분은 Table 2 와 같다. 수분함량은 71.01 $\sim 71.67 \%$, 조단백질은 $19.51 \sim 20.48 \%$, 조지방은 $6.31 \sim 7.05 \%$ 그리고 조회분은 $2.15 ~ 2.40 \%$ 로 시료들 사이에 유의한 차이가 없었다. 양념돈육의 처리구별 일반성분 함량에 차이가 없는
것은 원료돈육의 상태와 양념소스의 성분이 같은 데서 오는 결과로 여겨진다.

\section{양념돈육의 표면색깔}

양념돈육의 색깔을 측정한 결과는 Table 3 과 같다. 밝기를 나타내는 $\mathrm{L}^{*}$ 값은 $\mathrm{T} 0$ 및 $\mathrm{T} 1$ 이 $\mathrm{T} 2$ 및 $\mathrm{T} 3$ 보다 유의하게 낮았다 $(p<0.05)$. 그리고 적색도인 a 값은 시료들 사이에 유의한 차이 가 없었으며, 황색도인 $\mathrm{b}^{*}$ 값은 T2 및 T3가 T0 및 $\mathrm{T} 1$ 보다 유의 하게 높았다( $p<0.05)$. 식육의 색깔은 육색소인 myoglobin의 세 가지 유도체 즉, 환원형의 진홍색 deoxymyoglobin, 산소형 의 선홍색 oxymyoglobin, 그리고 산화형의 암갈색 metmyoglobin의 비율에 영향을 받으며, 이 세 가지 유도체의 상대적 인 비율이 $\mathrm{L}^{*}, \mathrm{a}^{*}$ 및 $\mathrm{b}^{*}$ 값에 영향을 미친다[26]. 본 연구에서 적포도주의 함유량이 많은 양념돈육인 T2 및 T3가 T0 및 T1보 다 $\mathrm{L}^{*}$ 값이 높게 나타난 것은 적포도주에 함유되어 있는 anthocyanin색소[10]가 영향을 미친 것으로 생각되고, $\mathrm{b}^{*}$ 값이 높은 것은 레드와인 숙성 중 생성된 황적색의 pyranoanthocyanin [14]이 영향을 미친 것으로 생각된다.

\section{양념돈육의 기계적 물성}

양념돈육의 기계적 물성으로 측정한 hardness (경도), springiness (탄성), cohesiveness (점착성), gumminess (뭉침 성) 및 chewiness (씹힘성)은 Table 4 와 같다. 양념돈육의 경도, 탄성, 점착성, 뭉침성 및 씹힘성은 $\mathrm{T} 0, \mathrm{~T} 1, \mathrm{~T} 2$ 및 $\mathrm{T} 3$ 사이에 유의한 차이가 없었다. 기계적 물성으로 나타내는 경도는 식 품을 변형시키는데 필요한 힘을, 탄성은 변형 후 원상회복하 는데 필요한 힘을, 응집성은 결합하려는 힘을, 뭉침성은 뭉치 려는 힘을, 씹힘성은 씹는데 필요한 힘을 나타낸다[28]. 따라서

Table 2. Chemical composition of seasoning pork meat (\%)

\begin{tabular}{lcccc}
\hline \multirow{2}{*}{ Traits } & \multicolumn{4}{c}{ Seasoning pork meat } \\
\cline { 2 - 5 } & $\mathrm{T} 0^{1)}$ & $\mathrm{T}^{2)}$ & $\mathrm{T} 2^{3)}$ & $\mathrm{T}^{4)}$ \\
\hline Moisture & $71.04 \pm 1.98^{5)}$ & $71.43 \pm 1.17$ & $71.01 \pm 3.21$ & $71.67 \pm 2.19$ \\
Crude protein & $19.51 \pm 1.05$ & $19.63 \pm 1.99$ & $20.48 \pm 1.52$ & $19.55 \pm 2.36$ \\
Crude fat & $7.05 \pm 1.82$ & $6.56 \pm 1.21$ & $6.31 \pm 0.94$ & $6.93 \pm 1.10$ \\
Crude ash & $2.40 \pm 0.10$ & $2.38 \pm 0.18$ & $2.20 \pm 0.09$ & $2.15 \pm 0.11$ \\
\hline
\end{tabular}

${ }^{1 \sim 4)}$ Same as in Table 1.

${ }^{5)} \mathrm{Mean} \pm \mathrm{SD}$

Table 3. Surface color of seasoning pork meat

\begin{tabular}{ccccc}
\hline \multirow{2}{*}{ Traits } & \multicolumn{4}{c}{ Seasoning pork meat } \\
\cline { 2 - 5 } & $\mathrm{T} 0^{1)}$ & $\mathrm{T} 1^{2)}$ & $\mathrm{T} 2^{3)}$ & $\mathrm{T}^{4)}$ \\
\hline $\mathrm{L}^{*}$ & $65.22 \pm 2.30^{5) \mathrm{b} 6)}$ & $65.51 \pm 1.10^{\mathrm{b}}$ & $70.20 \pm 1.92^{\mathrm{a}}$ & $69.44 \pm 2.11^{\mathrm{a}}$ \\
$\mathrm{a}^{*}$ & $13.74 \pm 1.73$ & $13.56 \pm 1.01$ & $14.21 \pm 2.11$ & $14.60 \pm 1.19$ \\
$\mathrm{~b}^{*}$ & $8.01 \pm 0.95^{\mathrm{b}}$ & $8.18 \pm 1.15^{\mathrm{b}}$ & $12.25 \pm 1.87^{\mathrm{a}}$ & $13.07 \pm 1.05^{\mathrm{a}}$ \\
\hline
\end{tabular}

\footnotetext{
${ }^{1 \sim 5)}$ Same as in Table 2.

${ }^{6}$ Values with different superscripts within the same row and column are significantly different at $p<0.05$, respectively.
} 
Table 4. Rheological properties of seasoning pork meat

\begin{tabular}{lccrr}
\hline \multirow{2}{*}{ Traits } & \multicolumn{4}{c}{ Seasoning pork meat } \\
\cline { 2 - 5 } & $\mathrm{T}^{1)}$ & \multicolumn{1}{c}{$\mathrm{T}^{2)}$} & $\mathrm{T}^{3}$ & $\mathrm{~T}^{4}$ \\
Hardness $\left(\mathrm{g} / \mathrm{cm}^{2}\right)$ & $4.72 \pm 1.01^{5)}$ & $4.81 \pm 0.75$ & $4.81 \pm 0.59$ & $4.71 \pm 0.81$ \\
Springiness(\%) & $69.12 \pm 2.19$ & $70.93 \pm 1.72$ & $69.34 \pm 2.75$ & $70.10 \pm 1.52$ \\
Cohesiveness(\%) & $65.51 \pm 1.98$ & $65.91 \pm 2.87$ & $67.65 \pm 2.65$ & $66.40 \pm 2.10$ \\
Gumminess $(\mathrm{kg})$ & $717.99 \pm 38.93$ & $696.79 \pm 52.12$ & $714.38 \pm 50.09$ & $700.63 \pm 29.87$ \\
Chewiness $(\mathrm{g})$ & $178.92 \pm 19.21$ & $180.34 \pm 29.65$ & $181.88 \pm 18.23$ & $184.14 \pm 26.39$ \\
\hline
\end{tabular}

\footnotetext{
${ }^{1 \sim 5)}$ Same as in Table 2.
}

식육을 그대로 이용하는 경우는 경도, 씹힘성 등이 연도와 관 련된 품질을 나타내고, 육제품은 경도, 탄성, 뭉침성, 응집성 등이 조직감의 품질결정에 중요하다고 생각된다. 이러한 연도 및 조직감에 영향을 미치는 요인으로서는 지방함량, 사후 근 원섬유의 상태, 결체조직 등[11,18,30]이 있다. 따라서 동일한 조건의 돈육등심을 이용한 양념돈육이기 때문에 기계적 조직 감에 영향을 미치지 않았고, 숙성에 이용한 적포도주는 양념 돈육의 기계적 조직감에는 효과가 없는 것으로 나타났다.

\section{양념돈육의 $\mathrm{pH}, \mathrm{VBN}$ 함량 및 TBARS값}

양념돈육의 $\mathrm{pH}, \mathrm{VBN}$ 함량 및 TBARS값은 Table 5 와 같다. 양념돈육의 $\mathrm{pH}$ 는 5.17 5.20으로 시료들 사이에 유의한 차이 가 없었다. 이와 같은 결과는 간장소스를 이용한 양념돈육의 $\mathrm{pH}$ 가 5.20이라는 Hah 등[13]의 결과와 비슷하였으며, Choi와 Lee [5]가 간장 양념돈육의 $\mathrm{pH}$ 가 5.59 라는 결과보다는 낮았다.

양념돈육의 VBN함량은 $24.99 \sim 26.53 \mathrm{mg} \%$ 로서 $\mathrm{T} 0, \mathrm{~T} 1, \mathrm{~T} 2$ 및 T3 사이에 유의한 차이가 없는 것으로 나타나 적포도주가 양념돈육의 $\mathrm{VBN}$ 함량에 영향을 미치지 않음을 확인하였다. $\mathrm{VBN}$ 함량은 단백질이 많이 함유된 식품의 신선도를 예측하는 수단으로 이용되고 있는데, 신선 돈육등심의 VBN함량이 11 $12 \mathrm{mg} \%$ 인 점을 감안하면[19] 본 연구의 VBN함량은 높은 경향 이었다. 이것은 간장을 기본양념으로 사용한 것이 원인인 것으 로 생각되는데, 간장 제조과정에서 발생한 $\mathrm{VBN}$ 이 양념돈육의 $\mathrm{VBN}$ 함량을 증가시키는 요인으로 작용했을 것으로 여겨진다.

TBARS값은 지방의 산패정도를 예측하는데 이용된다. 양념 돈육의 TBARS값은 $\mathrm{T} 0, \mathrm{~T} 1, \mathrm{~T} 2$ 및 $\mathrm{T} 3$ 가 각각 $0.47,0.39,0.29$ 및 $0.30 \mathrm{mg} \mathrm{MA} / \mathrm{kg}$ 으로 $\mathrm{T} 2$ 및 $\mathrm{T} 3$ 가 $\mathrm{T} 0$ 및 $\mathrm{T} 1$ 보다 유의하게 낮았다 $(p<0.05)$. 즉 양념돈육에 적포도주를 첨가하지 않거나 $5 \%$ 정도를 첨가하는 것보다 $10 \%$ 나 $15 \%$ 정도를 첨가하여 숙
성하면 TBARS값을 낮게 하여 지방의 산패를 지연시키는 것으 로 나타났으며, 이것은 적포도주에 함유되어 있는 페놀화합물 의 항산화작용[1]에 기인한 것으로 생각된다. 그리고 본 연구 의 TBARS값은 Choi와 Lee [5]의 $0.20 \sim 0.23 \mathrm{mg} \mathrm{MA} / \mathrm{kg}$ 보다 는 높았으나, Kim 등[21]이 3일 저장된 양념돈육의 TBARS값 이 $0.61 \sim 1.01 \mathrm{mg} \mathrm{MA} / \mathrm{kg}$ 이라는 결과보다는 낮았고, 이들은 양념돈육의 TBARS값이 높은 것은 양념돈육에 첨가된 여러 가지 양념들이 영향을 미친 것으로 해석하였다.

\section{양념돈육의 지방산조성}

적포도주의 첨가가 단기간 숙성하는 양념돈육의 지방산 조 성에 영향을 미치는 지를 관찰하기 위하여 지방산 조성을 실 험하고 그 결과를 Table 6에 나타내었다. 양념돈육의 포화지방 산은 $\mathrm{T} 0, \mathrm{~T} 1, \mathrm{~T} 2$ 및 $\mathrm{T} 3$ 가 각각 $37.646 \%, 38.601 \%, 37.704 \%$ 및 $39.105 \%$ 이고, 불포화지방산은 각각 $62.354 \%, 61.399 \%$, $62.296 \%$ 및 $60.895 \%$ 로 서로 유의한 차이가 없어서 적포도주 숙성이 양념돈육의 지방산조성에 영향을 미치지 않는 것을 확인하였다. 그리고 가장 많이 함유된 포화지방산은 palmitic acid $\left(\mathrm{C}_{16: 0}\right)$ 로 $23.555 \sim 24.499 \%$ 였고, 불포화지방산은 oleic acid $\left(\mathrm{C}_{18.1)}\right.$ 로 $44.217 \sim 44.718 \%$ 가 함유되어 있었다. 이것은 돈 육등심의 palmitic acid가 $24.493 \sim 24.871 \%$ 이며, oleic acid가 43.182 43.617\%라는 Yang 등[34]의 보고와 비슷한 경향이었 고, Jung 등[17]이 적포도주를 첨가한 돈육 패티의 포화지방산 이 35.85 37.76\% 이고, 불포화지방산은 $62.24 \sim 64.20 \%$ 로 적포 도주의 첨가가 지방산조성에 영향을 미치지 않았다는 결과와 일치하는 경향이었다.

\section{양념돈육의 유리아미노산 함량}

적포도주 숙성 양념돈육의 유리아미노산 함량을 측정한 결

Table 5. $\mathrm{pH}, \mathrm{VBN}$ content and TBARS value of seasoning pork meat

\begin{tabular}{lcccc}
\hline \multirow{2}{*}{ Traits } & \multicolumn{4}{c}{ Seasoning pork meat } \\
\cline { 2 - 5 } & \multicolumn{1}{c}{$\mathrm{T}^{1)}$} & \multicolumn{1}{c}{$\mathrm{T}^{2)}$} & $\mathrm{T}^{3)}$ \\
$\mathrm{nyH}$ & $\left.5.20 \pm 0.04^{5}\right)$ & $5.17 \pm 0.02$ & $5.16 \pm 0.02$ & $5.17 \pm 0.03$ \\
VBN (mg\%) & $25.97 \pm 1.95$ & $25.13 \pm 2.37$ & $24.99 \pm 1.11$ & $26.53 \pm 1.57$ \\
TBARS (mg MA/kg) & $\left.0.47 \pm 0.06^{\mathrm{a} 6}\right)$ & $0.37 \pm 0.02^{\mathrm{b}}$ & $0.29 \pm 0.04^{\mathrm{c}}$ & $0.30 \pm 0.02^{\mathrm{c}}$ \\
\hline
\end{tabular}

\footnotetext{
${ }^{1 \sim 6)}$ Same as in Table 3.
} 
Table 6. Fatty acid composition of seasoning pork meat (\%)

\begin{tabular}{|c|c|c|c|c|}
\hline \multirow{2}{*}{ Fatty Acid } & \multicolumn{4}{|c|}{ Seasoning pork meat } \\
\hline & $\mathrm{T} 0^{1)}$ & $\mathrm{T}^{2)}$ & $\mathrm{T} 2^{3)}$ & $\mathrm{T} 3^{4)}$ \\
\hline C14:0 & $\left.1.703 \pm 0.083^{5}\right)$ & $1.549 \pm 0.162$ & $1.451 \pm 0.102$ & $1.648 \pm 0.172$ \\
\hline C14:1 & $0.049 \pm 0.052$ & $0.033 \pm 0.021$ & $0.040 \pm 0.019$ & $0.033 \pm 0.011$ \\
\hline C15:0 & $0.061 \pm 0.027$ & $0.049 \pm 0.021$ & $0.063 \pm 0.016$ & $0.065 \pm 0.017$ \\
\hline $\mathrm{C} 15: 1$ & $0.067 \pm 0.061^{\mathrm{b} 6)}$ & $0.126 \pm 0.095^{\mathrm{a}}$ & $0.114 \pm 0.057^{\mathrm{ab}}$ & $0.119 \pm 0.077^{\mathrm{ab}}$ \\
\hline $\mathrm{C} 16: 0$ & $23.777 \pm 0.985$ & $24.499 \pm 1.094$ & $23.555 \pm 0.829$ & $24.191 \pm 1.199$ \\
\hline $\mathrm{C} 16: 1$ & $2.928 \pm 0.597$ & $2.917 \pm 0.386$ & $3.211 \pm 0.823$ & $3.021 \pm 0.536$ \\
\hline $\mathrm{C} 17: 0$ & $0.261 \pm 0.010^{\mathrm{a}}$ & $0.247 \pm 0.009^{\mathrm{a}}$ & $0.295 \pm 0.015^{\mathrm{a}}$ & $0.179 \pm 0.008^{\mathrm{b}}$ \\
\hline $\mathrm{C} 17: 1$ & $0.270 \pm 0.007^{b}$ & $0.261 \pm 0.007^{b}$ & $0.320 \pm 0.011^{\mathrm{a}}$ & $0.179 \pm 0.005^{\mathrm{c}}$ \\
\hline $\mathrm{C} 18: 0$ & $10.793 \pm 2.109$ & $11.203 \pm 0.113$ & $11.297 \pm 0.098$ & $11.739 \pm 1.011$ \\
\hline $\mathrm{C} 18: 1$ & $44.217 \pm 3.028$ & $44.427 \pm 1.009$ & $44.645 \pm 1.823$ & $44.718 \pm 2.978$ \\
\hline $\mathrm{C} 18: 2$ & $12.970 \pm 1.928$ & $11.751 \pm 1.001$ & $12.086 \pm 0.092$ & $11.063 \pm 2.137$ \\
\hline $\mathrm{C} 18: 3$ & $0.872 \pm 0.083^{\mathrm{a}}$ & $0.845 \pm 0.091^{\mathrm{a}}$ & $0.854 \pm 0.059^{\mathrm{a}}$ & $0.606 \pm 0.072^{b}$ \\
\hline C20:0 & $0.747 \pm 0.038$ & $0.750 \pm 0.069$ & $0.767 \pm 0.057$ & $0.767 \pm 0.041$ \\
\hline C20:1 & $0.412 \pm 0.034$ & $0.398 \pm 0.044$ & $0.398 \pm 0.051$ & $0.344 \pm 0.039$ \\
\hline $\mathrm{C} 20: 2$ & $0.117 \pm 0.011$ & $0.125 \pm 0.009$ & $0.115 \pm 0.008$ & $0.166 \pm 0.015$ \\
\hline C20:3 & $0.381 \pm 0.008$ & $0.435 \pm 0.017$ & $0.430 \pm 0.009$ & $0.558 \pm 0.010$ \\
\hline C20:4 & $0.071 \pm 0.003$ & $0.081 \pm 0.007$ & $0.083 \pm 0.007$ & $0.088 \pm 0.008$ \\
\hline $\mathrm{C} 21: 0$ & $0.075 \pm 0.004^{\mathrm{a}}$ & $0.036 \pm 0.003^{b}$ & $0.033 \pm 0.003^{b}$ & $0.061 \pm 0.002^{\mathrm{a}}$ \\
\hline C23:0 & $0.088 \pm 0.002$ & $0.098 \pm 0.004$ & $0.102 \pm 0.006$ & $0.104 \pm 0.004$ \\
\hline C24:0 & $0.143 \pm 0.017^{b}$ & $0.171 \pm 0.021^{\mathrm{b}}$ & $0.143 \pm 0.022^{b}$ & $0.352 \pm 0.011^{\mathrm{a}}$ \\
\hline SFA & $37.646 \pm 3.091$ & $38.601 \pm 3.119$ & $37.704 \pm 1.682$ & $39.105 \pm 2.751$ \\
\hline UFA & $62.354 \pm 4.121$ & $61.399 \pm 2.092$ & $62.296 \pm 2.714$ & $60.895 \pm 2.954$ \\
\hline MUFA & $47.943 \pm 2.119$ & $48.162 \pm 2.851$ & $48.728 \pm 1.502$ & $48.414 \pm 1.825$ \\
\hline PUFA & $14.411 \pm 1.009$ & $13.237 \pm 1.221$ & $13.568 \pm 0.991$ & $12.481 \pm 1.171$ \\
\hline UFA/SFA & $1.656 \pm 0.101$ & $1.591 \pm 0.115$ & $1.652 \pm 0.131$ & $1.557 \pm 0.098$ \\
\hline Total & 100 & 100 & 100 & 100 \\
\hline
\end{tabular}

${ }^{1 \sim 6)}$ Same as in Table 3.

Table 7. Free amino acid content of seasoning pork meat (ppm)

\begin{tabular}{|c|c|c|c|c|}
\hline \multirow{2}{*}{ Free amino acid } & \multicolumn{4}{|c|}{ Seasoning pork meat } \\
\hline & $\mathrm{T} 0^{1)}$ & $\mathrm{T} 1^{2)}$ & $\mathrm{T}^{3)}$ & $\mathrm{T}^{4)}$ \\
\hline Phosphoserine & $45.50 \pm 3.95^{5) \mathrm{a} 6)}$ & $23.70 \pm 2.83^{b}$ & $18.76 \pm 2.91^{\mathrm{c}}$ & $17.26 \pm 3.01^{\mathrm{c}}$ \\
\hline Taurine & $134.05 \pm 15.21^{\mathrm{a}}$ & $112.19 \pm 10.09^{b}$ & $105.47 \pm 9.29^{b}$ & $110.66 \pm 10.91^{\mathrm{b}}$ \\
\hline Aspartic acid & $56.30 \pm 5.25^{c}$ & $67.98 \pm 2.91^{\mathrm{b}}$ & $74.30 \pm 5.21^{\mathrm{a}}$ & $69.14 \pm 3.99^{\mathrm{ab}}$ \\
\hline Threonine & $175.92 \pm 21.09$ & $173.62 \pm 31.24$ & $175.71 \pm 9.82$ & $195.95 \pm 12.95$ \\
\hline Serine & $181.33 \pm 31.28$ & $192.72 \pm 21.67$ & $204.01 \pm 19.55$ & $208.95 \pm 22.73$ \\
\hline Glutamic acid & $1,365.71 \pm 93.72^{b}$ & $1,716.73 \pm 101.92^{\mathrm{a}}$ & $1,821.23 \pm 88.39^{\mathrm{a}}$ & $1,717.09 \pm 99.18^{\mathrm{a}}$ \\
\hline Proline & $636.67 \pm 78.23$ & $644.96 \pm 55.21$ & $682.26 \pm 59.01$ & $694.86 \pm 33.39$ \\
\hline Glycine & $171.36 \pm 24.56$ & $186.95 \pm 31.29$ & $188.83 \pm 19.93$ & $193.17 \pm 22.29$ \\
\hline Alanine & $263.06 \pm 33.43$ & $254.20 \pm 18.99$ & $263.25 \pm 29.92$ & $287.29 \pm 30.01$ \\
\hline Citrulline & $42.32 \pm 3.12^{\mathrm{a}}$ & $31.54 \pm 2.10^{b}$ & $27.90 \pm 1.99^{c}$ & $33.52 \pm 5.12^{b}$ \\
\hline Valine & $162.15 \pm 9.92$ & $146.61 \pm 36.21$ & $162.51 \pm 12.18$ & $163.43 \pm 10.10$ \\
\hline Isoleucine & $163.44 \pm 29.81$ & $142.76 \pm 18.88$ & $154.62 \pm 22.90$ & $173.21 \pm 25.55$ \\
\hline Leucine & $379.14 \pm 34.98$ & $344.55 \pm 41.29$ & $359.28 \pm 30.33$ & $399.02 \pm 45.58$ \\
\hline Tyrosine & $141.68 \pm 31.12$ & $133.02 \pm 28.88$ & $124.90 \pm 21.02$ & $140.07 \pm 40.99$ \\
\hline Phenylalanine & $247.05 \pm 29.77$ & $238.49 \pm 44.42$ & $233.07 \pm 24.78$ & $261.02 \pm 35.65$ \\
\hline Orinithine & $7.89 \pm 1.11^{\mathrm{a}}$ & $7.89 \pm 0.98^{\mathrm{a}}$ & $7.62 \pm 2.19^{\mathrm{a}}$ & $4.84 \pm 2.09^{\mathrm{b}}$ \\
\hline Lysine & $78.92 \pm 3.61^{b}$ & $76.15 \pm 5.77^{b}$ & $80.75 \pm 2.95^{\mathrm{b}}$ & $89.84 \pm 3.44^{\mathrm{a}}$ \\
\hline Histidine & $35.62 \pm 2.01^{\mathrm{a}}$ & $37.97 \pm 1.77^{\mathrm{a}}$ & $26.99 \pm 1.03^{\mathrm{b}}$ & $28.80 \pm 2.11^{b}$ \\
\hline Total & $4,288.11 \pm 151.72^{b}$ & $4,532.03 \pm 221.19^{\mathrm{ab}}$ & $4,711.46 \pm 389.01^{\mathrm{a}}$ & $4,788.12 \pm 254.56^{\mathrm{a}}$ \\
\hline
\end{tabular}

${ }^{1 \sim 6)}$ Same as in Table 3. 
과는 Table 7과 같다. 유리아미노산 총량은 $\mathrm{T} 0, \mathrm{~T} 1, \mathrm{~T} 2$ 및 $\mathrm{T} 3$ 가 각각 4,288.11, 4,532.03, 4,711.46 및 4,788.12 ppm으로 적포도 주로 숙성한 양념돈육에서 유의하게 높았다( $p<0.05)$. 가장 많 은 유리아미노산은 glutamic acid로 $\mathrm{T} 0, \mathrm{~T} 1, \mathrm{~T} 2$ 및 $\mathrm{T} 3$ 가 각각 $1,365.71,1,716.73,1,821.23$ 및 1,717.09 ppm으로 적포도주로 숙성한 양념돈육에서 유의하게 높았다 $(p<0.05)$. 유리아미노산 은 여러 가지 맛에 영향을 미치는데, 그 중에서 glutamic acid 는 IMP와 함께 풍미를 향상시키는 전구물질이다[20]. 따라서 적포도주는 양념돈육의 맛과 풍미에 영향을 미칠 수 있음을 추측하게 하였으며, 이것은 유리아미노산의 생성과정에 적포 도주에 함유된 알코올, 무기산, 유기산 등[36]이 단백질을 변성 시켜 단백질 분해효소의 작용이 쉽도록 하여 나타난 결과로 여겨진다.

이상의 결과에서 단기간 숙성시키는 양념돈육에 적포도주 를 첨가하면 색깔을 좋게 하여 소비자들에게 구매 옥구를 일 으킬 수 있으며, 지방의 산패를 억제하고, 유리아미노산의 생 성을 촉진하여 기호성 향상에도 좋은 역할을 할 것으로 기대 된다.

\section{References}

1. Alonso, A. M., C. Domínguez, A. Domonico, and C. G. Guillén Barroso. 2002. Determination of antioxidant power of red and white wines by a new electrochemical method and its correlation with polyphenolic content. J. Agric. Food Chem 50, 3112-3115.

2. Aruoma, O. 1996. I eat, drink and be healthy. Chemistry in Britain 32, 29-31.

3. Bhattarai, S., V. H. Tran, and C. C. Duke. 2001. The stability of gingerol and shogaol in aqueous solution. J. Pharm Sci. 90, 1658-1664.

4. Buege, A. J. and S. D. Aust. 1978. Microsomal Lipid Peroxidation, In methods in Enzymology, In Gleischer S. and L. Parker (ed.), pp. 302-310, Vol. 52, Academic Press Inc., New York.

5. Choi, W. S. and K. T. Lee. 2002. Quality changes and shelf-life of seasoned pork with soy sauce or Kochujang during chilled storage. Korean J. Food Sci. Ani. Resour. 22, 240-246.

6. Daglia, M., M. Stauder, A. Papetti, C. Signoretto, G. Giusto, P. Canepari, C. Pruzzo, and G. Gazzani. 2010. Isolation of red wine components with anti-adhesion and anti-biofilm activity against Streptococcus mutans. Food Chem 119, 11821188.

7. Feijóo, O., A. Moreno, and E. Falqué. 2008. Content of transand cis-resveratrol in Galician white and red wines. J. Food Composition Anal. 21, 608-613.

8. Folch, J., M. Lee, and G. H. Sloane-Stanley. 1957. A simple metnod for the isolation and purification of total lipids from animal tissues. J. Biol. Chem 226, 497-507.

9. Frankel, E. N., J. Kanner, J. B. German, E. Parks, and J. E.
Kinsella. 1993. Inhibition of oxidation of human low-density lipoprotein by phenolic substances in red wine. Lancet 341, 454-457.

10. García-Marino, M., J. M. Hernández-Hierro, J. C. Rivas-Gonzalo, and M. T. Escribano-BailÓn. 2010. Colour and pigment composition of red wines obtained from co-maceration of Tempranillo and Graciano varieties. Anal. Chem Acta. 660, 134-142.

11. Gelse, K., E. Pöschl, and T. Aigner. 2003. Collagens-structure, function, and biosynthesis. Adv. Drug Delivery Rev. 55, 1531-1546.

12. Guo, J. Y., H. Li, H. Wang, C. L. Yuan, and R. M. Xie. 2007. The influence of red wine on lipid of golden hamsters plasma. Agric. Sci. China 6, 996-1001.

13. Hah, K. H., C. N. Ahn, S. T. Joo, G. B. Park, N. J. Sung, K. H. Park, I. S. Kim, S. K. Jin, and K. Y. Chung. 2005. Physical characteristics of seasoning pork during aging at cold temperature. Korean J. Food Sci. Ani. Resour. 25, 397-402.

14. He, J., C. Santos-Buelga, A. M. Silva, N. Mateus, and V. de Freitas. 2006. Isolation and structural characterization of new anthocyanin-derived yellow pigments in aged red wine. J. Agric. Food Chem 54, 9598-9603.

15. Jang, M., L. Cai, G. O. Udeani, K. V. Slowing, C. F. Thomas, C. W. W. Beecher, H. H. S. Fong, N. R. Fransworth, A. D. Kinghorn, R. G. Metha, R. C. Moon, and J. M. Pezzuto. 1997. Cancer chemopreventive activity of resveratrol, a natural product derived from grapes. Science 275, 218-229.

16. Jeon, M. S., K. H. Sohn, S. H. Chae, H. K. Park, and H. J. Jeon. 2002. Color characteristics of Korean traditional soy sauces prepared under different processing conditions. $J$. Korean Soc. Food Sci. Nutr. 31, 32-38.

17. Jung, I. C., D. H. Youn, and Y. H. Moon. 2007. Quality and palatability of pork patty containing wine. J. Korean Soc. Food Sci. Nutr. 36, 355-360.

18. Jung, I. C., M. S. Kim, W. C. Shin, and Y. H. Moon. 1997. Physico-chemical properties for utilization of aging index of cold storage beef tenderloin. J. Korean Soc. Food Sci. Nutr. 26, 647-653.

19. Jung, I. C., Y. H. Moon, and S. J. Yang. 2006. Effect of feeding of citrus byproduct on the physicochemical properties and palatability of pork loin during growing period. Korean J. Life Sci. 16, 1164-1168.

20. Kawai, M., A. Okiyama, and Y. Ueda. 2002. Taste enhancements between various amino acid and IMP. Chemical Sense 27, 739-745.

21. Kim, I. S., S. K. Jin, S. N. Kang, I. C. Hur, and S. Y. Choi. 2009. Effect of olive-oil prepared tomato powder (OPTP) and refining lycopene on the physicochemical and sensory characteristics of seasoned raw pork during storage. Korean J. Food Sci. Ani. Resour. 29, 334-339.

22. Kim, M. B., Y. J. Oh, and S. B. Lim. 2009. Physicochemical characteristics of galic from Daejeong Jeju and major cultivation areas in Korea. Korean J. Culinary Res. 15, 59-66.

23. Korean Food \& Drug Administration. 2002. Food Code pp. 212-251, Munyoungsa, Seoul.

24. Lee, H. J., B. S. Yoo, and S. Y. Byun. 2000. Differences in 
phenolic acids between Korean ginsengs and mountain ginsengs. Korean J. Biotechnol. Bioeng. 15, 323-328.

25. Lee, K. S., Y. H. Moon, and I. C. Jung. 2008. Effect on the quality characteristics of beef jerky ripened by wine. J. Life Sci. 18, 1538-1542.

26. Lindahl, G., A. C. Enfält, G. von Seth, Ă. Joseli, I. Hedebro-Velander, H. J. Andersen, M. Braunschweig, L. Andersson, and K. Lundström. 2004. A second mutant allele (V1991) at the PRKAG3 (RN) locus-II. Effect on colour characteristics of pork loin. Meat Sci. 66, 621-627.

27. Modun, D., I. Music, J. Vukovic, I. Brizic, V. Katalinic, A. Obad, I. Palada, Z. Dujic, and M. Boban. 2008. The increase in human plasma antioxidant capacity after red wine consumption is due to both plasma urate and wine polyphenols. Atherosclerosis 197, 250-256.

28. Moon, Y. H., S. J. Yang, and I. C. Jung. 2007. Feeding effect of citrus byproduct pulp on the quality characteristics of Hanwoo. J. East Asian Soc. Dietary. Life 17, 227-233.

29. Opie, L. H. and S. Lecour. 2007. The red wine hypothesis: from concepts to protective signalling molecules. Eur. Heart J. 28, 1683-1693.

30. Platter, W. J., J. D. Tatum, K. E. Belk, S. R. Koontz, P. L. Champman, and G. C. Smith. 2005. Effects of marbling and shear force on consumer's willingness to pay for beef strip loin steaks. J. Anim Sci. 83, 890-899.
31. Seong, P. N., J. H. Kim, S H. Cho, D. W. Kang, G. H. Kang, B. Y. Park, J. M. Lee, J. H. Jung, and D. H. Kim. 2010. The effects of salt and $\mathrm{NaNO}_{2}$ on fatty acid composition, free amino acids, microbial counts and sensory characteristics of dry-cured ham processed under Korean environment. Korean J. Food Sci. Ani. Resour. 30, 435-442.

32. Song, H. P., S. L. Shim, I. S. Jung, J. H. Kim, K. M. Noh, H. Y. Seo, D. H. Kim, and K. S. Kim. 2009. Analysis of volatile organosulfur compounds in Korean Allium species. Korean J. Food Preserv. 16, 929-937.

33. Szmitko, P. E. and S. Verma. 2005. Antiatherogenic potential of red wine: clinician update. Am J. Physiol. Heart Circ. Physiol. 288, 2023-2030.

34. Yang, S. J., S. M. Koh, T. I. Yang, I. C. Jung, and Y. H. Moon. 2006. Feeding effect of citrus byproduct on the quality of cross-bred black pig in Jeju island. J. Korean Soc. Food Sci. Nutr. 35, 897-902.

35. Youn, D. H., Y. H. Moon, and I. C. Jung. 2007. Changes in quality of pork patty containing red wine during cold storage. J. Life Sci. 17, 91-96.

36. Zhang, Y. L., J. B. Chen, Y. Lei, Q. Zhou, S. Q. Sun, and I. Noda. 2010. Discrimination of different red wine by fourier-transform infrared and two-dimensional infrared correlation spectroscopy. J. Mol. Struct. 974, 144-150.

\section{초록 : 적포도주 숙성 양념돈육의 품질특성 및 유리아미노산 함량 \\ 박경숙 ${ }^{1} \cdot$ 이경수 ${ }^{2} \cdot$ 박현숙 $^{1} \cdot$ 최영준 $^{1} \cdot$ 강세주 $^{3} \cdot$ 양종범 ${ }^{4} \cdot$ 현재석 $^{5} \cdot{\text { 정인철 }{ }^{1} \star}^{*}$ 문윤희 ${ }^{6}$ \\ ( ${ }^{1}$ 대구공업대학 호텔외식조리계열, ${ }^{2}$ 영남이공대학 식음료조리계열, ${ }^{3}$ 축산물등급판정소, ${ }^{4}$ 동남보건대학 식품 생명과학과, ${ }^{5}$ 제주산업정보대학 식품영양과, ${ }^{6}$ 경성대학교 식품생명공학과)}

본 연구는 적포도주의 첨가가 양념돈육의 품질특성 및 유리아미노산 함량에 미치는 영향을 검토하였다. 양념 돈육은 물을 $25 \%$ 첨가한 것(대조구, $\mathrm{T} 0$ ), 물 $20 \%$ 와 적포도주 $5 \%$ 를 첨가한 것(T1), 물 $15 \%$ 와 적포도주 $10 \%$ 를 첨 가한 것(T2), 그리고 물 $10 \%$ 와 적포도주 $15 \%$ 를 첨가한 것(T3) 등 네 종류의 양념돈육을 제조하고, 일반성분, 표면 색깔, 기계적 조직감, $\mathrm{pH}, \mathrm{VBN}$ 함량, TBARS값, 지방산 조성 및 유리아미노산 함량을 분석하였다. 수분, 조단백질, 조지방 및 조회분은 시료들 사이에 유의한 차이가 없었다. $\mathrm{L}^{*}$ 및 b 값은 $\mathrm{T} 2$ 및 $\mathrm{T} 3$ 가 $\mathrm{T} 0$ 및 $\mathrm{T} 1$ 보다 유의하게 높았 으며 $(p<0.05), \mathrm{a}^{*}$ 값은 시료들 사이에 유의한 차이가 없었다. 기계적 조직감, $\mathrm{pH}, \mathrm{VBN}$ 함량, 포화지방산 및 불포화 지방산은 시료들 사이에 유의한 차이가 없었으나 TBARS값은 적포도주를 첨가하지 않은 $\mathrm{T} 0$ 가 가장 높았다 ( $p \times 0.05)$. 유리아미노산 함량은 적포도주를 $10 \%$ 및 $15 \%$ 첨가한 $\mathrm{T} 2$ 및 $\mathrm{T} 3$ 가 $\mathrm{T} 0$ 보다 유의하게 높았다 $(p<0.05)$. 